\title{
Az őrszemnyirokcsomó extracapsularis áttétének jelentősége az emlőrák sebészi kezelésében
}

\author{
The importance of extracapsular extension of the sentinel node metastasis \\ in the surgical treatment of breast cancer
}

\author{
MARÁZ RÓBERT ${ }^{1,2, @, ~ V E N C Z E L ~ L A ́ S Z L O ́ ㅁ, ~ S I K O R S Z K I ~ L A ́ S Z L O ́ ~}{ }^{1}$, AMBRÓZAY ÉVA $^{3}$, \\ SERFŐZŐ ORSOLYA ${ }^{3}$, RAJTÁR MÁRIA ${ }^{4}$, CSERNI GÁBOR ${ }^{5,6}$ \\ ${ }^{1}$ Bács-Kiskun Megyei Kórház, a Szegedi Tudományegyetem Általános Orvostudományi Kar Oktatókórháza, \\ Általános Sebészeti Osztály (osztályvezető főorvos: dr. Sikorszki László) \\ ${ }^{2}$ Bács-Kiskun Megyei Kórház, a Szegedi Tudományegyetem Általános Orvostudományi Kar Oktatókórháza, \\ Onkoradiológiai Központ (osztályvezető főorvos: dr. Horváth Zsolt) \\ ${ }^{3}$ MaMMa Egészségügyi Zrt. Kecskeméti Centrum (centrumvezető főorvos: dr. Ambrózay Éva) \\ ${ }^{4}$ Bács-Kiskun Megyei Kórház, a Szegedi Tudományegyetem Általános Orvostudományi Kar Oktatókórháza, \\ Nukleáris Medicina Osztály (osztályvezető főorvos: dr. Rajtár Mária) \\ ${ }^{5}$ Bács-Kiskun Megyei Kórház, a Szegedi Tudományegyetem Általános Orvostudományi Kar Oktatókórháza, \\ Általános Patológiai Osztály (osztályvezető főorvos: dr. Cserni Gábor) \\ ${ }^{6}$ Szegedi Tudományegyetem, Általános Orvostudományi Kar, Patológiai Intézet, \\ Szeged (intézetvezető: dr. Tiszlavicz László)
}

\begin{abstract}
Bevezetés: Az örszemnyirokcsomó-biopszia (SNB) bevezetésével a hónalji blokkdissectiók (ABD) aránya jelentősen csökkent. Az extracapsularis terjedés (ECT) jelenléte az örszemnyirokcsomókban azonban bizonytalan jelentőségü. Módszer: Retrospektív vizsgálatunkban 635 T1-T2N0M0 klinikai stádiumú emlörákos beteg adatait elemeztük, akiknél SNB-t végeztünk 2014 és 2018 között. Az esetek 25\%-ában (158 beteg) igazolódott őrszemnyirokcsomó- (SN) áttét. Az SN-áttétes betegeinket két csoportra osztottuk aszerint, hogy igazolódott-e az SN-ben ECT, vagy nem. Vizsgálatunk fö célja az volt, hogy elemezzük a masszív (>3) nyirokcsomóáttét arányát az ECT-negatív és -pozitív betegeknél, akiknél ABD történt. Eredmények: Az ECT-negatív csoportba 91/158 beteg (58\%), míg az ECT-pozitívba 67/158 beteg (42\%) került. Az ECT-negatív betegek 42\%-ánál, az ECT-pozitívok 69\%-ánál történt ABD. Nem találtunk szignifikáns különbséget a következő változókban: életkor, tumorméret, szövettani típus, grade és lymphovascularis invázió jelenléte, valamint a hormon- és HER2-receptorok arányai között. Amennyiben az SN-ben nem igazolódott ECT, de ABD történt, akkor a pN1-érintettség aránya $82 \%$-os, míg a pN2+pN3 aránya $18 \%$-os volt. Az ECT-pozitív ABD-s csoportban a pN1-érintettség $60 \%$-os volt, míg a pN2+pN3 arány 40\%-osnak bizonyult, amely az ECT-negatív csoport kétszerese; ez a különbség szignifikáns $(p=0,038)$. Következtetések: Az ECT a hónalj masszív nyirokcsomó-érintettség prediktora, ezért ha ECT igazolódik, akkor ez egy olyan tényező, amelyet az ABD-ről való döntésben figyelembe kell venni.
\end{abstract}

Kulcsszavak: extracapsularis nyirokcsomó-érintettség, őrszemnyirokcsomó-biopszia, hónalji blokkdissectio, emlőrák

Introduction: The introduction of sentinel node biopsy (SNB) has led to a significant decrease of axillary lymph node dissections (ALND). The importance of the extracapsular extension (ECE) in the sentinel lymph node (SN) remains unclear. Method: The data of 635 patients with T1-T2N0M0 invasive breast cancer who underwent SNB between 2014 and 2018 were retrospectively analysed. $25 \%$ of the SNB patients (158) had metastasis in the SNs. These patients were grouped based on the presence or absence of ECE. The main objective of our study was to analyse the occurrence of massive ( $>3$ ) node metastasis in the case of ECE negative and ECE positive patients, where ALND was performed. Results: There were $91 / 158$ patients $(58 \%)$ in the ECE negative group and $67 / 158$ patients $(42 \%)$ in the ECE positive group. ALND was performed in $42 \%$ of the ECE negative and in $69 \%$ of the ECE positive patients. There were no significant differences in the mean age of the patients; size, histological type and grade of the tumours, presence of lymphovascular invasion and proportion of hormone and HER2 receptor positivities. In the ECE negative ALND group, $\mathrm{pN} 1$ involvement was $82 \%$, pN2 $+\mathrm{pN} 3$ involvement represented $18 \%$ of cases. In the ECE positive ALND group, $\mathrm{pN} 1$ involvement was $60 \%$, pN2+pN3 involvement was found in $40 \%$ of cases. The presence of ECE was associated with greater axillary disease burden. These results show a significant difference $(p=0.038)$. Conclusions: ECE of the

${ }^{\circledR}$ Levelezési cim/Corr. address: Dr. Maráz Róbert, 6000 Kecskemét, Nyíri út 38., Tel.: +36 76516 700/5425, Fax: 0676481219 , E-mail: marazrobert2010@gmail.com 
$\mathrm{SN}$ is an important predictor for non-sentinel lymph node involvement. These data suggest, when ECE is confirmed, it is a further factor to be considered in deciding about ALND.

Keywords: breast cancer, extracapsular extension, sentinel lymph node biopsy, axillary lymph node dissection

Beérkezett: 2019. december 2.; elfogadva: 2020. február 10.

\section{Bevezetés}

A hónalji nyirokcsomóstátus jelenleg is az emlőrák egyik leglényegesebb önálló és független prognosztikai tényezője. ${ }^{1,2}$ A régebben rutinszerüen végzett sok, kedvezőtlen mellékhatással (érzéskiesés, mozgáskorlátozottság, lymphoedemema) járó hónalji blokkdissectiót (ABD) az 1990es évek közepén megismert örszemnyirokcsomó-biopszia (SNB) váltotta fel. ${ }^{3,4} \mathrm{Ez}$ a technika biztosítja a regionális áttétképződés legvalószínűbb helyének, az őrszemnyirokcsomóknak (SN) az azonosítását. Az SN-ek részletes patológiai feldolgozásával a staging pontosabbá tehető, ha nem igazolódik bennük áttét, akkor az ABD elkerülhető. ${ }^{5}$ Számos vizsgálat igazolta, hogy ha az SN-ben a nyirokcsomó tokját áttörő, úgynevezett extracapsularis terjedést (ECT) igazolnak, akkor a többi hónalji nyirokcsomóban a masszív érintettség ( $>3$ nyirokcsomóáttét) aránya szignifikánsan megnő. ${ }^{6-9}$ Közleményünk elsődleges célja az volt, hogy megvizsgáljuk az ECT jelentőségét a klinikai gyakorlatban.

\section{Anyag és módszer}

Retrospektív vizsgálatunkban 635 primer, invazív, T1T2N0M0 klinikai stádiumú emlőrákos beteg adatait elemeztük, akiknél őrszemnyirokcsomó-biopsziát (SNB) végeztünk osztályunkon 2014. január 1. és 2018. december 31. között. Minden esetben - a preoperatív kivizsgálás részeként - fizikális, mammográfiás, emlö- és hónalji ultrahangvizsgálat (UH) történt. Az invazív daganat diagnózisát az emlőből végzett core-biopsziával igazoltuk. Amennyiben a hónalji UH-val patológiás nyirokcsomó ábrázolódott, akkor abból vékonytü-aspirációs cytológiai (FNAC) vizsgálatot végeztünk. SNB csak azoknál a betegeknél történt, akiknél a preoperatív vizsgálatok során nem igazolódott hónalji nyirokcsomóáttét. A neoadjuváns terápiában részesült pácienseket kizártuk vizsgálatunkból. A betegeknél a tumor nagyságától függően emlőmegtartó mütétet vagy mastectomiát végeztünk. Nem tapintható elváltozás esetén ROLL (radio-guided occult lesion localization) vagy drótjelöléses technika került alkalmazásra, és az eltávolított anyag specimen mammográfiás vizsgálata is megtörtént. Az SNB-t kettős jelöléses módszerrel végeztük, izotóp $\left({ }^{99 \mathrm{~m}} \mathrm{Tc}\right.$-jelölt kolloidális albumin) és festékjelöléses (patentkék) módszer együttes alkalmazásával. Az SNB során minden kék és/ vagy radioaktív nyirokcsomó eltávolításra került. Az axilla további kezelését az alábbi tényezők határozták meg: az intraoperatív lenyomat cytológia (IC), a végleges patológiai SN-státus, az ECT jelenléte az SN-ben (1. ábra), valamint az onkoteam javaslata. Vizsgálatunk első felében (2014-től 2016-ig) akkor végeztünk ABD-t, ha az IC vagy a végleges szövettani vizsgálat metasztázist igazolt az SNben. Vizsgálatunk második felében (2017-től 2018-ig) az ACOSOG Z-0011-es vizsgálat ${ }^{10}$ és a III. Emlörák Konszenzus Konferencia ajánlásainak ${ }^{11}$ figyelembevételével, rutinszerüen nem végeztünk IC-t, csak akkor, ha kettőnél több SN került eltávolításra a mütét során. Ebben a periódusban csak akkor végeztünk ABD-t, ha az IC vagy a végleges szövettani vizsgálat kettőnél több metasztatikus nyirokcsomót igazolt, vagy az SN-ben ECT igazolódott. Egy vagy kettő hónalji áttét esetén (ha nem igazolódott ECT) az esetek nagy részében nem történt $\mathrm{ABD}$, helyette hónalji sugárterápiás kezelést $(\mathrm{ST})$ végeztünk. ${ }^{12} \mathrm{ABD}$ során az axilla I-es és II-es szintjén lévő legalább 10 nyirokcsomó eltávolítására törekedtünk. A patológiai lelet tartalmazta a

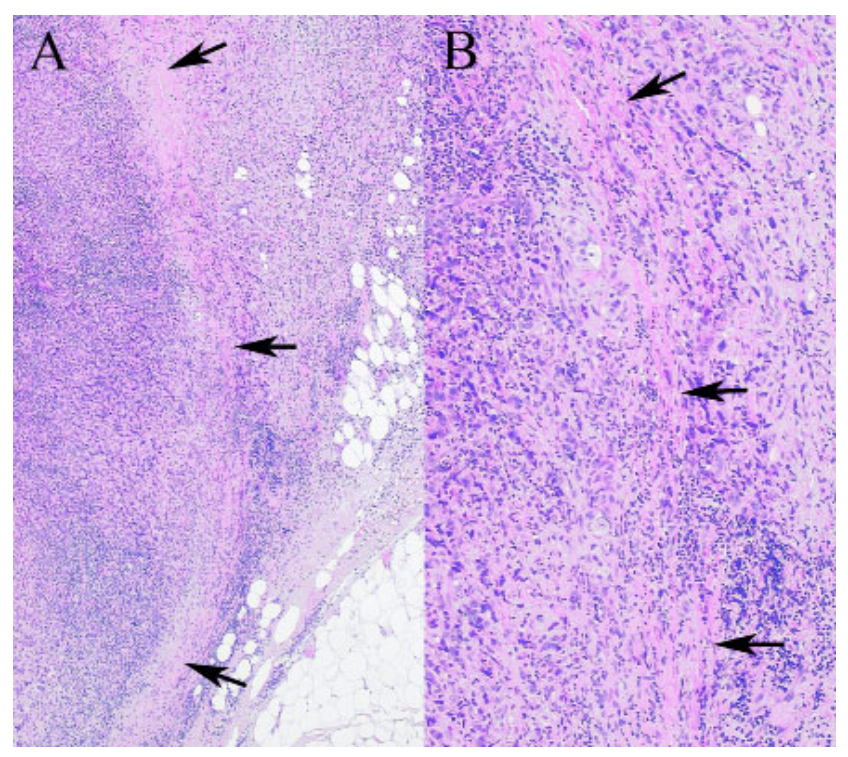

1. ábra. Az extracapsularis terjedés szövettani képe. Extracapsularis terjedés - a nyirokcsomó (bal oldal) tokján (nyilak) áttörő, és a környező hónalji zsírszövetet infiltráló (jobb oldal) metasztázis két különböző nagyítással; A: ×40, B ×100; hematoxili-eozin festés 


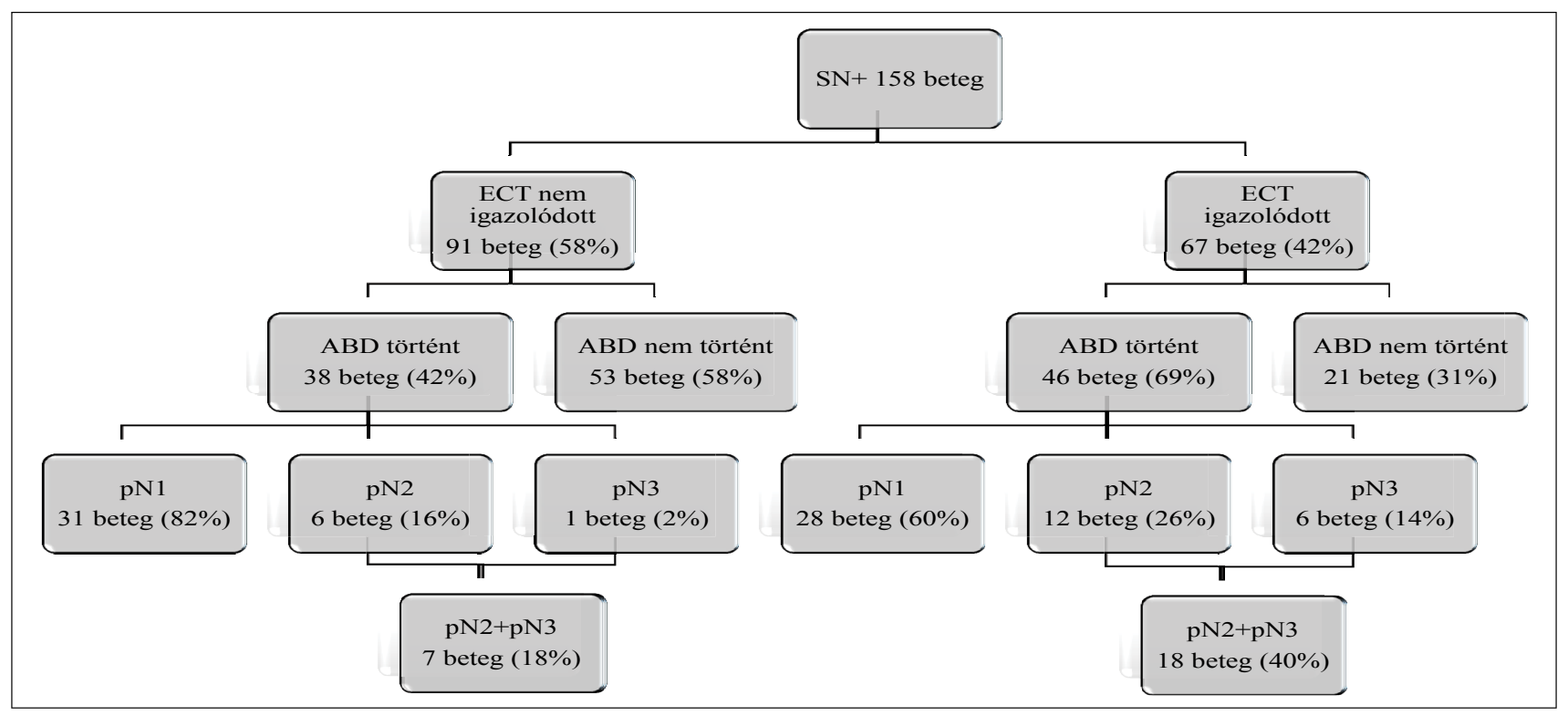

2. ábra. $\mathrm{Az} \mathrm{ABD}$ és a nyirokcsomó-érintettség aránya az SN-áttétes, ECT-negatív és ECT-pozitív betegeknél. ABD: hónalji blokkdissectio; ECT: extracapsularis terjedés; SN+: őrszemnyirokcsomó-áttétes; SNB: ôrszemnyirokcsomó-biopszia

legfontosabb prognosztikai tényezőket, a patológiai tumorméretet, a tumor szövettani típusát, a szövettani grade-et, az ösztrogén (ER) - progeszteron (PR) receptorstátust és a HER2-státust. Vizsgáltuk még a lymphovascularis invázió (LVI) jelenlétét, a mitotikus aktivitási indexet, az SN-ben lévő áttét méretét, valamint az ECT-t is. Az SN végleges szövettani vizsgálata kb. 2 mm-es makroszkópos szeletek $3 \mathrm{db}, 250$ mikrométerenkénti metszete alapján történt, hematoxilin-eozin festéssel. Az SN-t akkor tekintettük pozitívnak, ha mikrometasztázis vagy makrometasztázis volt benne. A mütét utáni sugárkezelés és onkológiai terápia az intézményben alkalmazott protokollok szerint történt. Betegeinket két csoportra osztottuk aszerint, hogy igazolódott-e az SN-ben ECT, vagy nem (2. ábra). Az ECT-negatív és -pozitív csoport adatait tovább vizsgáltuk, azokat a betegeket emeltük ki, akiknél ABD történt. Vizsgálatunk fó célja az volt, hogy elemezzük a masszív nyirokcsomó-érintettség (>3 nyirokcsomóáttét) arányát az ECT-negatív és ECT-pozitív betegeknél, akiknél ABD történt. A statisztikai számításokat Pearson szerinti chi-négyzet próbával végeztük el (www.vassarstats.net). Statisztikailag szignifikáns különbségnek a $p<0,05$ valószínüségi érték számított.

\section{Eredmények}

A vizsgált 5 éves időszakban 635 esetben végeztünk SNB-t. A betegek 25\%-ánál (158 beteg) észleltünk áttétet az SN-ekben. Az SN-áttétes betegeket két csoportra osztottuk: „A” kar: akiknél nem igazolódott ECT, illetve „B” kar: akiknél ECT igazolódott. Az első csoportba 91 beteg tartozott (58\%), míg a másodikba 67 beteg (42\%) került. Az „A” karon a betegek 42\%-ánál történt ABD, míg ez az arány a „B” karon $69 \%$-os volt (2. ábra). A vizsgált időszakban az ECT-pozitív betegeknél ABD elvégzésére törekedtünk, de az esetek 31\%-ánál ez nem történt meg. Ennek több oka is volt. Kezdetben nem került elég hangsúly az ECT jelenlétének fontosságára, más esetben a primer tumor kedvező szövettani típusa (tubularis carcinoma) alapján került mellőzésre az ABD ${ }^{13}$ Előfordult olyan eset is, hogy a vizsgált időszak első felében, a kórházunkban alkalmazott francia nomogram becsülte alacsonynak a további nyirokcsomó-érintettség kockázatát, és ezért nem történt további hónalji mütét. ${ }^{14}$ A vizsgálati időszak második felében az ECT-pozitivitás ellenére több esetben az ABD helyett hónalji ST történt, és előfordult olyan helyzet is, hogy a beteg nem vállalta az ABD-t, helyette ST mellett döntött.

Vizsgálatunk fő célja az ABD-n átesett ECT-negatív és ECT-pozitív betegek adatainak további elemzése volt. Az alapvető beteg- és tumortulajdonságok összehasonlítását ebben a két csoportban az 1. táblázat mutatja. Nem találtunk szignifikáns különbséget a betegek életkora, a tumoruk mérete, szövettani típusa, grade-je és a lymphovascularis invázió jelenléte között. Az ösztrogén-, progeszteron- és HER2-receptorok pozitivitási arányának eloszlása is egyenletes volt a két csoportban. Jelentős különbséget az ECT-negatív, illetve ECT-pozitív betegek hónalji nyirokcsomó-áttéteinek arányában találtunk. Amennyiben az SN-ben nem igazolódott ECT, de mégis $\mathrm{ABD}$ történt, akkor a $\mathrm{pN} 1$-érintettség aránya $82 \%$-os volt, míg a masszív nyirokcsomó-érintettség ( $\mathrm{pN} 2+\mathrm{pN} 3)$ a betegek 18\%-ánál jelentkezett. Az ECT-pozitív esetekben végzett $A B D$-s csoportban a pN1-érintettség 60\%-os volt, míg a masszív érintettség $40 \%$-osnak bizonyult, és ez az ECT-negatív csoportnál észlelt gyakoriságnak hozzávetőleg a kétszerese; a különbség szignifikáns volt $(p=0,038)$ (1. táblázat). Tovább elemeztük az ECT-pozitív ABD-s csoportot aszerint, hogy az ECT mérete $\leq 2 \mathrm{~mm}$ vagy $>2 \mathrm{~mm}$ volt (2. táblázat). A masszív nyirokcsomó-érin- 
1. táblázat. Az ABD-n átesett ECT-pozitív és ECT-negatív betegek legfontosabb jellemzői

\begin{tabular}{|c|c|c|c|}
\hline Jellemzők & $\begin{array}{l}\text { ECT-pozitív és } \\
\text { ABD történt }\end{array}$ & $\begin{array}{c}\text { ECT-negatív és } \\
\text { ABD történt }\end{array}$ & $p$ value \\
\hline Betegszám & 46 & 38 & \\
\hline Életkor & & & 0,05 \\
\hline$\leq 50$ & 4 & 10 & \\
\hline $51-70$ & 28 & 15 & \\
\hline$>70$ & 14 & 13 & \\
\hline Tumorméret & & & 0,66 \\
\hline$\leq 20 \mathrm{~mm}$ & 24 & 18 & \\
\hline$>20 \mathrm{~mm}$ & 22 & 20 & \\
\hline Tumor szövettani típusa & & & 0,5 \\
\hline IDC & 40 & 31 & \\
\hline ILC & 5 & 4 & \\
\hline Egyéb & 1 & 3 & \\
\hline Grade & & & 0,85 \\
\hline I & 6 & 5 & \\
\hline II & 24 & 14 & \\
\hline III & 16 & 19 & \\
\hline Lymphovascularis invázió & & & 0,11 \\
\hline Igen & 14 & 18 & \\
\hline Nem & 32 & 20 & \\
\hline Ösztrogénreceptor-státus & & & 0,5 \\
\hline Pozitív & 40 & 31 & \\
\hline Negatív & 6 & 7 & \\
\hline Progeszteronreceptor-státus & & & 0,48 \\
\hline Pozitív & 38 & 29 & \\
\hline Negatív & 8 & 9 & \\
\hline HER2-receptorstátus & & & 0,68 \\
\hline Pozitív & 4 & 2 & \\
\hline Negatív & 42 & 36 & \\
\hline Nyirokcsomóstátus & & & 0,038 \\
\hline $\mathrm{pN} 1$ & 31 & 28 & \\
\hline $\mathrm{pN} 2$ & 6 & 12 & \\
\hline $\mathrm{pN} 3$ & 1 & 6 & \\
\hline
\end{tabular}

ABD: hónalji blokkdissectio; ECT: extracapsularis terjedés; IDC: invazív ductális carcinoma (nem speciális típusú emlörák); ILC: invazív lobuláris carcinoma; HER2: human epidermal growth factor receptor 2

2. táblázat. Az ABD-n átesett ECT-pozitív betegek nyirokcsomó-érintettségének jellemzői az ECT mérete alapján

\begin{tabular}{lccc}
\hline Jellemzők & $\begin{array}{c}\text { ECT } \leq 2 \text { mm és } \\
\text { ABD történt }\end{array}$ & $\begin{array}{c}\text { ECT }>2 \text { mm és } \\
\text { ABD történt }\end{array}$ & $p$ value \\
\hline Nyirokcsomóstátus & & & 0,13 \\
\hline Összes beteg & 19 & 27 & \\
\hline pN1 & 14 & 14 & \\
pN2 & 3 & 9 & \\
pN3 & 2 & 4 & \\
\hline
\end{tabular}

ABD: hónalji blokkdissectio; ECT: extracapsularis terjedés; mm: milliméter 
tettség aránya magasabbnak tünt az utóbbi csoportban (26\%, illetve $48 \%$ ), de ez a különbség nem volt szignifikáns.

\section{Megbeszélés}

Az SNB bevezetésével a hónalj sebészete jelentős változásokon ment keresztül, a korábban rutinszerüen végzett $\mathrm{ABD}$ egyre inkább háttérbe szorult. Ez a tendencia tovább folytatódott, hiszen a 2013. évi St. Galleni Konszenzus Konferencia ${ }^{15}$ ajánlásként fogadta el, hogy a Z-0011-vizsgálat ${ }^{10}$ beválasztási kritériumainak megfelelő betegeknél az ABD biztonságosan elhagyható. A Z-0011-vizsgálatnál csak olyan betegek feleltek meg az elöírásoknak, akiknél T1-T2N0M0 emlörákot szervmegtartó mütéttel, ép szélekkel távolítottak el, legfeljebb két SN-ben mutatkozott áttétük, és a mütétet követően teljes mellbesugárzás is történt tangenciális mezőkből az adjuváns onkológiai kezelésük részeként. ${ }^{5,10} \mathrm{Az}$ SN-ben lévő makroszkópos ECT azonban kizáró tényező volt, ilyenkor nem volt elengedhető az ABD elvégzése. ${ }^{10} \mathrm{Ez}$ az ajánlás a későbbeikben sem változott (2015-ös, 2017-es, 2019-es St. Galleni Konszenzus Konferencia), ${ }^{16-18}$ de az ECT jelenlétének fontosságára nem került elég hangsúly, a korai emlörákos betegeket érintő, legfrissebb 2019-es ESMO ajánlás például nem is említi azt. ${ }^{19}$ Vizsgálatunk elemzése során felmerült az a kérdés, hogy a klinikai gyakorlatban, SNB elvégzése után, vajon mennyire kerül figyelembevételre az ECT a további terápiás döntésben, hiszen ennek meglétére az SN-ben csak a végleges patológiai feldolgozás után derül fény. Vajon minden esetben rögzítésre kerül az ECT, történik-e mindig második lépésben ABD, az indokolt-e? Saját anyagunkat elemezve a 635 SNB-n átesett betegek 11\%-ánál (67 beteg), és az SN-áttétet tartalmazó betegek 42\%-ánál (67/158 beteg) igazolódott $\mathrm{ECT}$ mikroszkópos vizsgálattal. E betegeknél az esetek 30\%-ánál nem történt meg a következő lépésben az $\mathrm{ABD}$ (2. ábra). Ennek különbözö okait már elemeztük, de kiemelésre érdemes az a tény, hogy az esetek 36\%-ában (föleg a vizsgált időszak elején), egyáltalán nem került említésre az ECT jelenléte, további 36\%-nál pedig az ECT tényének birtokában sem végeztünk ABD-t, helyette hónalji ST történt, az ECT-töl többnyire függetlenül.

Saját tapasztalatunk alapján megállapíthatjuk, hogy elöfordulhatnak olyan esetek, amikor nem került elég hangsúly az ECT meglétére. A helyzetet tovább nehezíti az a tény is, hogy klinikai vizsgálatokban sajnos nem egységes az ECT dokumentálása. Legtöbb esetben az ECT jelenléte csak „igen” vagy „nem” jelzéssel van említve, máshol „körülírt” vagy „kiterjedt” minősítést kap, vagy úgy osztják be, hogy csak a nyirokcsomó tokját érinti, vagy a nyirokcsomó melletti szövetekre is ráterjed az áttét. ${ }^{6}$ Bizonyos közlemények fontosnak tartják legalább két kategória megkülönböztetését, mely szerint az ECT mérete $\leq 2 \mathrm{~mm}$ vagy $>2 \mathrm{~mm},{ }^{20}$ $\mathrm{mi}$ is ezt követtük gyakorlatunkban (2. táblázat). Van olyan munkacsoport is, amelyik még tovább részletezve 5 cso- portba sorolja az ECT-t. ${ }^{21}$ Abban egyetértés van, hogy szükség lenne az ECT jelenlétének standardizált rögzítésére, legtöbben a $\leq 2 \mathrm{~mm}$ és $>2 \mathrm{~mm}$ kategóriák használatát javasolják. ${ }^{20-23}$

Az ECT jelentőségére először Cserni $(2001)^{24}$, valamint Stitzenberg és munkatársai $(2003)^{25}$ hívták fel a figyelmet, véleményük szerint az ECT jelenléte az SN-ben fontos elörejelzője a hónalj további nyirokcsomó-érintettségének. Az ECT gyakran társul LVI-vel is. ${ }^{26}$ Több munkacsoport vizsgálta azt is, hogy az ECT mennyiben befolyásolja a betegségmentes túlélést (DFS) és a teljes túlélést (OS). Gruber és munkatársai szerint az ECT rosszabb OS-sel és DFS-sel társul, de a különbség nem szignifikáns. ${ }^{27}$ Vane és munkatársai 2111 beteg adatainak elemzése során megállapították, hogy a lokális és regionális kiújulást, a DFS és az OS arányait szignifikánsan nem befolyásolta az ECT jelenléte, a távoli áttétek aránya ugyan valamivel magasabb volt, de ez sem volt szignifikáns különbség. ${ }^{23} \mathrm{~A}$ legtöbb közlemény szerint a cT1-2cN0 cM0 csoportban az ECT elöfordulása $30-50 \%$ körüli. ${ }^{22,23}$ Ezeknél a betegeknél 30-65\%-os a $>3$ nyirokcsomóáttét aránya ${ }^{6-9,22,23}$ így kijelenthető, hogy az ECT a hónalj masszív nyirokcsomóérintettségének prediktora. Ezen adatok függvényében megállapítható, hogy ECT jelenléte esetén egy tényezővel több szólhat az ABD elvégzése mellett, vagy ennek hiányában a célzott hónalji ST alkalmazása mellett. ${ }^{28}$ Saját anyagunkban, az SNB-n átesett betegeknél az irodalmi adatokhoz képest kisebb arányban fordult elő ECT (11\%), nem találtunk szignifikáns különbséget a betegek és a tumorok legtöbb jellemzöje között az ECT-negatív és ECT-pozitív csoportban. Az ECT-negatív betegeknél a masszív nyirokcsomó-érintettség aránya 18\%, míg az ECT-pozitív betegeknél $40 \%$ volt, a különbség szignifikánsnak bizonyult ( $p=$ 0,038) (1. táblázat). A jelenleg futó klinikai vizsgálatokban (BOOG 2013-07, POSNOC, SINODAR, SENOMAC trial) cT1-2cN0 betegeket randomizálnak, akiknél mastectomia vagy emlőmegtartó mütét történik. SNB (maximum 3 makrometasztázissal) és további hónalji terápia (ABD vagy a hónalj célzott ST-je) kerül összehasonlításra, és az ECT jelenléte nem kizáró tényező. ${ }^{29-32}$ A lezáruló vizsgálatok elemzése során a jövőben talán még pontosabb válaszokat kaphatunk az ECT jelenlétének fontosságáról és a klinikai gyakorlatban betöltött szerepéről.

\section{Következtetések}

Amennyiben az SN-ben ECT igazolódik, akkor szignifikánsan nagyobb a masszív hónalji nyirokcsomó-érintettség ( $>3$ nyirokcsomóáttét) aránya, ezért ezeknél a betegeknél az ABD elvégzése komolyabban mérlegelendő. Amenynyiben ez nem történik meg, akkor a hónalj célzott sugárterápiás kezelése is szóba jöhet. Az ECT klinikai gyakorlatban betöltött pontos szerepéröl a jelenleg folyamatban lévő vizsgálatok lezárulása után lehet pontosabb következtetéseket levonni. 


\section{Irodalomjegyzék}

${ }^{1}$ Liman GH, Giuliano AE, Somerfield MR et al.: American Society of Clinical Oncology guideline recommendations for sentinel lymph node biopsy in early-stage breast cancer. J Clin Oncol 2005; 23: 7703-7720.

2 Zarenczan Dull B, Neuman HB: Management of the axilla. Surg Clin North Am 2013; 93: 429-444.

${ }^{3}$ Giuliano AE, Kirgan DM, Guenther JM et al.: Lymphatic mapping and sentinel lymphadenectomy for breast cancer. Ann Surg 1994; 220: 391-401.

${ }^{4}$ Cserni $G$ : Az örszemnyirokcsomó-biopszia szerepe az emlőrák ellátásában. Klinikai Onkológia 2018; 5: 173 178.

${ }^{5}$ Cserni G: Örszemnyirokcsomó-státus és hónalji blokkdissectio az emlőrák sebészi ellátásában. Orvosi Hetilap 2014; 155: 203-215.

${ }^{6}$ Nottegar A, Veronese N, Senthil M et al.: Extra-nodal extension of sentinel lymph node metastasis is a marker of poor prognosis in breast cancer patients: A systematic review and an exploratory meta-analysis. Eur J Surg Oncol 2016; 42: 919-925.

${ }^{7}$ Gooch J, King TA, Eaton A et al.: The extent of extracapsular extension may influence the need for axillary lymph node dissection in patients with T1-T2 breast cancer. Ann Surg Oncol 2014; 21: 2897-2903.

${ }^{8}$ Shigematsu H, Taguchi K, Koui H et al.: Clinical significance of extracapsular invasion at sentinel lymph nodes in breast cancer patients with sentinel lymph node involvement. Ann Surg Oncol 2015; 22: 2365-2371.

${ }^{9}$ Choi AH, Blount S, Perez MN et al.: Size of extranodal extension on sentinel lymph node dissection in the American college of surgeons' oncology group Z0011 trial era. JAMA Surg 2015; 150: 1141-1148.

${ }^{10}$ Giuliano AE, McCall L, Beitsch P et al.: Locoregional recurrence after sentinel lymph node dissection with or without axillary dissection in patients with sentinel lymph node metastases: the American College of Surgeons Oncology Group Z0011 randomized trial. Ann Surg 2010; 252: 426-432.

${ }^{11}$ Lázár Gy, Bursics A, Farsang $Z$ et al.: III. Emlőrák Konszenzus Konferencia - Az emlőrák korszerü sebészi kezelése. Magyar Onkológia 2016; 60: 194-207.

12 Goldhirsch A, Winer EP, Coates AS et al.: Personalizing the treatment of women with early breast cancer: highlights of the St. Gallen International Expert Consensus on the Primary Therapy of Early Breast Cancer 2013. Ann Oncol 2013; 24: 2206-2223.

${ }^{13}$ Polgár Cs, Kahán Zs, Csejtei A. et al.: III. Emlőrák Konszenzus Konferencia - Sugárterápiás irányelvek. Magyar Onkológia 2016; 60: 229-239.

${ }^{14}$ Cserni $G$ : Axillary sentinel lymph node micrometastases with extracapsular extension: a distinct pattern of breast cancer metastasis? J Clin Path 2008; 61: 115-118.

${ }^{15}$ Cserni G, Bezsenyi I, Markó L: Patient's choice on axillary lymph node dissection following sentinel lymph node micrometastasis - first report on prospective use of nomogram in very low risk patients. Pathol Oncol Res 2013; 19: 211-216.

${ }^{16}$ Coates AS, Winer EP, Goldhirsch A et al.: Tailoring therapies - improving the management of early breast cancer: St. Gallen International Expert Consensus on the Primary Therapy of Early Breast Cancer 2015. Ann Oncol 2015; 26: 1533-1546.

${ }^{17}$ Curigliano G, Burstein HJ, Winer EP et al.: De-escalating and escalating treatments for early-stage breast cancer: the St. Gallen International Expert Consensus Conference on the Primary Therapy of Early Breast Cancer 2017. Ann Oncol 2017; 28: 1700-1712.

18 Burstein HJ, Curigliano G, Loibl S et al.: Estimating the Benefits of Therapy for Early Stage Breast Cancer The St. Gallen International Consensus Guideline for the Primary Therapy of Early Breast Cancer 2019. Ann Oncol 2019; doi: 10.1093/annonc/mdz235.

${ }^{19}$ Cardoso F, Kyriakides S, Ohno S et al.: Early breast cancer: ESMO Clinical Practice Guidelines for diagnosis, treatment and follow up. Ann Oncol 2019; doi: 10.1093/ annonc/mdz189.

${ }^{20}$ Gooch J, King TA, Eaton A et al.: The extent of extracapsular extension may influence the need for axillary lymph node dissection in patients with T1-T2 breast cancer. Ann Surg Oncol 2014; 21: 2897-2903.

${ }^{21}$ Kanyilmaz G, Findik S, Xavuz BB et al.: The significance of extent of extracapsular extension in patients with T1-2 and N1 breast cancer. Eur J Breast Health 2018; 14: 218 224.

${ }^{22}$ Schwentner L, Dayan D, Wöckel A et al.: Is extracapsular nodal extension in sentinel nodes a predictor for nonsentinel metastasis and is there an impact on survival parameters? - A retrospective single center cohort study with 324 patients. Breast J 218; 4: 480-486.

${ }^{23}$ Vane MLG, Willemsen MA, van Roozendaal LM et al.: Extracapsular extension in the positive sentinel lymph node: a marker of poor prognosis in cT1-2N0 breast cancer patients? Breast Cancer Res Treat 2019; 3: 711718.

${ }^{24}$ Cserni G: Sentinel lymph-node biopsy-based prediction of further breast cancer metastases in the axilla. Eur $\mathrm{J}$ Surg Oncol 2001; 27: 532-538.

25 Stitzenberg KB, Meyer AA, Stern SL et al.: Extracapsular extension of the sentinel lymph node metastasis: a predictor of nonsentinel node tumor burden. Ann Surg 2003; 237: 607-613.

${ }^{26}$ Altinyollar $H$, Berberoglu $U$, Gulben $K$ et al.: The correlation of extranodal invasion with other prognostic parameters in lymph node positive breast cancer. J Surg Oncol 2007; 95: 567-571.

${ }^{27}$ Gruber G, Bonetti M, Nasi ML et al.: Prognostic value of extracapsular tumor spread for locoregional control in premenopausal patients with node-positive breast cancer treated with classical cyclophosphamide, methotrexate, and fluorouracil: long-term observations from International Breast Cancer Study Group Trial VI. J Clin Oncol 2005; 23: 7089-7097. 
${ }^{28}$ Lyman GH, Somerfield MR, Giuliano AE et al.: Sentinel lymph node biopsy for patients with early-stage breast cancer: 2016 American Society of Clinical Oncology clinical practice guideline update summary. J Oncol Pract 2017; 13: 196-198.

${ }^{29}$ van Roozendaal LM, de Wilt JH, van Dalen T et al.: The value of completion axillary treatment in sentinel node positive breast cancer patients undergoing a mastectomy: a Dutch randomized controlled multicentre trial (BOOG 2013-07). BMC Cancer 2015; 15: 610-625.

${ }^{30}$ Goyal A, Dodwell D: POSNOC: a randomised trial looking at axillary treatment in women with one or two sen- tinel nodes with macrometastases. Clin Oncol 2015; 27: 692-695.

31 Tinterri $C$, Canavese $G$, Bruzzi P et al.: SINODAR ONE, an ongoing randomized clinical trial to assess the role of axillary surgery in breast cancer patients with with one or two macrometastatic sentinel nodes. Breast 2016; 30: 197-200.

32 de Boniface J, Frisell J, Andersson Y et al.: Survival and axillary recurrence following sentinel node-positive breast cancer without completion axillary lymph node dissection: the randomized controlled SENOMAC trial. BMC Cancer 2017; 26: 379. 